Portland State University

PDXScholar

Anthropology Faculty Publications and

Presentations

Anthropology

2009

\title{
Advocating for Sri Lankan Migrant Workers: Obstacles and Challenges
}

Michele Ruth Gamburd

Portland State University, b5mg@pdx.edu

Follow this and additional works at: https://pdxscholar.library.pdx.edu/anth_fac

Part of the Social and Cultural Anthropology Commons

Let us know how access to this document benefits you.

\section{Citation Details}

Gamburd, Michele Ruth, "Advocating for Sri Lankan Migrant Workers: Obstacles and Challenges" (2009). Anthropology Faculty Publications and Presentations. 39.

https://pdxscholar.library.pdx.edu/anth_fac/39

This Post-Print is brought to you for free and open access. It has been accepted for inclusion in Anthropology Faculty Publications and Presentations by an authorized administrator of PDXScholar. Please contact us if we can make this document more accessible: pdxscholar@pdx.edu. 
Gamburd / Sri Lankan Migrant Workers

FEATURE: Distant Divides and Intimate Connections: Migrant Domestic Workers in Asia — Part 2. Part 1 appeared in Critical Asian Studies 40 (4) , 2008.

\section{ADVOCATING FOR \\ SRI LANKAN MIGRANT WORKERS}

Obstacles and Challenges

Michele R. Gamburd

ABSTRACT: Nearly a million Sri Lankan women labor as migrant workers, the vast majority in the Gulf Cooperation Council (GCC) countries in West Asia. They are poorly paid and vulnerable to a wide variety of exploitative labor practices at home and abroad. Despite the importance of worker remittances to the national economy, and in spite of Sri Lanka's history of organized labor and active political participation, migrants have received only anemic support from the state, labor unions, feminist organizations, and migrant-oriented nongovernmental organizations (NGOs). The article contextualizes Sri Lankan migration within larger-scale economic dynamics (such as global capitalist policies and processes) and local-level ideological formations (such as local political histories and culturally shaped gender norms). The author argues that political freedoms in destination countries have a significant effect on organizing activities in both host and sending nations. Comparing the Sri Lankan and Philippine situations, the author contends that the vibrant activism in the Philippines correlates with the liberal organizing climates in the EU and in East and Southeast Asia, while the paucity of organizing in Sri Lanka correlate with the strict repression of guest workers in the GCC. Compared to other destinations, the GCC countries give workers (particularly women) less chance for autonomous activities, are less open to labor organizing, and are less responsive to political protest.

After three decades of migration to the Gulf Cooperation Council (GCC) countries in West Asia, Sri Lankan migrants continue to face exploitative labor conditions abroad and anemic support at home. Despite the large number of transnational guest workers and the economic centrality of their remittances, migrants lack strong advocates among unions, nongovernmental organizations (NGOs), and government departments in Sri Lanka. ${ }^{1}$ In this article, I argue that to understand the puzzling paucity of labor activism requires an inquiry that encompasses not only the activities of Sri Lankan NGOs, unions, and government institutions, but also the wider economic and political context, particularly the international division of labor and the constraints that destination countries put on labor organizing and diplomatic activities.

Statistics highlight the importance of international labor migration to the Sri Lankan economy. The Sri Lankan Bureau of Foreign Employment (SLBFE) estimates the stock of overseas contract workers has increased steadily every year since this migration stream began in 1976, with about 1.2 million Sri Lankans working abroad in $2005 .^{2}$ Migrant laborers make up about 15 percent of the Sri Lankan work force, and their remittances contribute significantly to Sri Lanka’s foreign exchange earnings. ${ }^{3}$ In 2005, total remittances stood at over US\$1.9 billion; over 
half of this total, roughly US\$1 billion, came from the Gulf. ${ }^{4}$ In generating foreign earnings, private remittances (29 percent) come second after Sri Lanka's large garment industry (47 percent). ${ }^{5}$ Clearly, the country has a great financial stake in the remittances generated by migrant laborers, particularly those working in the Gulf.

Reflecting the increasing feminization of migrant work forces around the world, women make up two thirds of Sri Lanka’s overseas contract workers. Domestic servants or “housemaids” alone make up over half of Sri Lanka's migrants. ${ }^{6}$ Each migrant woman supports an average of five family members; thus Sri Lanka’s 800,000 female migrants support an estimated 4 million people, or a little over 20 percent of the nation's population of 19.5 million. ${ }^{7}$ Despite the large numbers of women working abroad and the significant percentage of the population dependent on their remittances, however, little organizing around migration as a woman's issue has taken place in either the public or the private sector in Sri Lanka. What gender norms and political-economic circumstances explain this lack of support?

In neoliberal economies, market-driven logic has unsettled older relations between citizens and the state. Aihwa Ong argues that people with valued skills have entitlements all over the world, while unskilled laborers are excluded from rights both in their host countries and at home. ${ }^{8}$ Because neoliberalism allows (even requires) the political liminality of some citizens, other ethical regimes (such as feminism, humanism, and religious traditions) and their representatives in civil society step in to protect individuals from the adverse effects of bare market forces. But to what extent can NGOs and labor unions protect workers in developing countries? In this essay, I explore what is happening, and, more importantly, what is not happening in Sri Lankan NGOs, labor unions and government administrative organs, traditional venues in which activists and state officials advocate for workers' and citizens' rights. I seek to identify the conditions that hamper state and civil society organizations in labor-sending countries from effectively advocating for guest workers abroad — from promoting, for example, higher wages, safer working conditions, and systematically honored contracts.

Explaining an absence or a lack is never easy, especially when examining an isolated case. Therefore I contrast the relative paucity of labor activism in Sri Lanka's migrant sector with the well documented, energetic organizing in another labor-sending country, the Republic of the Philippines. I argue that a major source of difference can be found in the economic and political conditions of the destination countries in which Sri Lankan and Filipina migrants work. Labor dynamics in the Gulf (which receives 90 percent of Sri Lanka's transnational domestic workers) contrast with those in various countries in East and Southeast Asia (especially Hong Kong, Japan, Taiwan, and Singapore), which together receive 60 percent of Filipina workers. In short, I suggest that differences in the labor climates in destination countries influence how energetically sending-country governments and other groups will agitate for migrant rights. Above and beyond these political issues, however, looms the overarching economic reality of a global capitalist economy that disadvantages migrant laborers from the global South.

This essay begins with a discussion of the global economy and an overview of the role of gender in the international division of labor. I then explore the working conditions of Sri Lanka’s transnational domestic servant, in the context of labor dynamics in the GCC (Gulf Cooperation Council) countries. Turning to the situation in the sending country, I consider activities undertaken by Sri Lankan NGOs, labor unions, and state institutions in support of migrant 
workers. To understand the transnational factors that constrain both labor and government in their activities and effectiveness, I compare labor-organizing climates in the GCC, Asia, and the European Union (EU). I then compare migration patterns in Sri Lanka and the Philippines to identify factors that promote and inhibit the support of migrant laborers. I conclude with a discussion of the challenges and obstacles faced by both labor and state actors in protecting transnational domestic workers in the global economy.

\section{Globalization, Gender, and Migration}

Since the end of World War II, theorists have struggled to explain the power imbalances between former colonies and former colonizers. ${ }^{9}$ They discuss dynamics between the global North and South. ${ }^{10}$ Despite different analytical perspectives, all agree that the concentration of capital and technology lies in the global North. Neoliberal economic policies have over the past twenty years polarized differences between countries and exacerbated the gap between rich and poor with countries. ${ }^{11}$ This situation provides the context in which transnational migrants move from poor, less developed nations to developed ones. ${ }^{12}$

Although globalization affects the entire world, dynamics are localized within regions and countries, thus research requires attention to ethnographic particulars. For example, modernization in the Gulf does not look entirely like modernization in North America and the European Union, especially if the social, cultural, and political context is taken into consideration. ${ }^{13}$ In the Gulf, strong states implement aggressive policies to marginalize migrants. Similarly, labor-sending countries occupy specific positions within the international economy and have unique histories of labor migration. To explain the paucity of support for migrant workers in Sri Lanka, I will examine labor conditions in the Middle East as well as the position that Sri Lanka holds in the international division of global labor and power.

All too often, explanations of transnational labor migration focus exclusively on large-scale demographic and economic factors. Anthropologists have argued that these explanations, while valuable, do not adequately account for other important influences, such as national politics, household relations, and gender norms, all of which affect the micro-processes of labor negotiations and in turn influence labor flows and work conditions. ${ }^{14}$ Gender relations in both sending and receiving countries matter in terms of what sorts of freedoms and empowerment local and migrant women have. ${ }^{15}$ Thus materials written about male migration do not necessarily apply to female migration, particularly when migrants go to the highly gender-segregated societies of the Middle East. In addition, women's mobilizing and organizing in their home and host countries take place within local contexts of existing gender norms and patterns.

In the past, scholars examining globalization have often assumed that women hold the fort at home while men migrate in the global economy. ${ }^{16}$ The transnational migration of women who work as domestic servants radically upsets the association of "female" with "the local," and challenges Euro-American commonsense assumptions that women reproduce families in the home. ${ }^{17}$ As part of their paid work, domestic servants take responsibility for care work outside the home (and country). As breadwinners, they earn money in the global economy, sending remittances to support their husbands and children back home. ${ }^{18}$ Despite these objective changes in women's activities, older gender values persist in both Sri Lanka and the Middle East. In the United Arab Emirates (UAE), for 
example, the labor laws do not cover work that takes place within a private home, thus excluding all transnational domestic workers in the country from labor protections. Similarly, Sri Lanka has no national regulations on domestic service, a reality that hinders government and NGO efforts in behalf of women doing this job abroad. Both in Sri Lanka and in the Gulf, gendered norms affect the structures and attitudes within which labor organizing and government initiatives on migrant women's behalf take place, contributing to the lack of support for migrant women.

\section{Women's Work Situation Abroad}

Understanding women's work situations abroad provides some context for considering the lack of labor and other activism in Sri Lanka around transnational domestic workers' issues. The prevailing labor conditions limit women's ability to resist exploitation. One aspect of disempowerment pertains to living conditions. In the Gulf, most housemaids live in their employers' residences, as do many housemaids in Singapore, Hong Kong, the United States, and the European Union. Research indicates that live-in housemaids have much less autonomy and freedom than do women with part-time or live-out arrangements. ${ }^{19}$ Live-in workers make less money per hour than live-out workers do and find it more difficult to differentiate work time from free time. Their employers allow them little privacy and feel free to call on their labor at any time of the day or night, blurring the line between "workplace" and "home." ${ }^{20}$ Live-ins depend on employers not only for employment but also for housing. In many cases, particularly in the Gulf, this arrangement is formalized with government regulations regarding residence and work permits; thus losing a job can jeopardize a migrant's right to stay in the host country. ${ }^{21}$ In addition, compared to live-out workers, live-in domestic servants generally are more vulnerable to exploitation and have fewer backup safety networks. ${ }^{22}$ Other disempowering work conditions pertain to women's mobility and their social roles within their sponsor's families. Domestic servants working in the Middle East often describe extensive curtailment of their mobility. Sri Lankan migrants regularly report to researchers and human rights organizations that their employers confiscated their passports to keep them "safe" — an action illegal under international law and International Labour Organization (ILO) conventions, and one that causes great logistical difficulties for housemaids who flee untenable work situations but cannot leave the country without proper documentation. ${ }^{23}$ Roughly half of the returned Sri Lankan migrants whom I interviewed stated that they never left their employers' houses during their entire two years abroad, or left only in the company of the sponsor's family. ${ }^{24}$ Many of these same interviewees claimed to find this situation reassuring, saying that the sponsor treated them like a daughter of the family. Yet scholars report that migrant domestic workers joke that being considered "one of the family" is a justification for greater exploitation in the employers' household. ${ }^{25}$ In addition, norms governing familial behavior often disadvantage young women, discouraging them from protesting against exploitative labor relations. ${ }^{26}$ Gendered norms for familial deference, combined with restrictions on female mobility, limit women's abilities to resist exploitation or escape threatening situations.

State-level regulations governing labor relations also influence women's work situations and their ability to resist exploitation. In many GCC countries, labor laws cover male laborers but do not protect household workers. ${ }^{27}$ The same situation occurs in Taiwan, where the Labour Standards Law does not apply to domestic workers. ${ }^{28}$ In Hong 
Kong, labor laws do apply to foreign domestic servants, but are rarely enforced against middle- and upper-class employers. ${ }^{29}$ Other state-level issues that affect women's work situations include the availability of health care, regulations surrounding bringing in family members, and the possibility of becoming citizens in the host country. For example, in Europe, migrant women can have relationships with local men, marry them, gain citizenship, and establish transnational families where members have different nationalities. ${ }^{30}$ Women who work in countries with a strong discourse of human rights and an active civil society receive more support from the social system in their country of employment and have more opportunities to organize and mobilize. And women have greater control over their situations if they are free to leave their place of employment and seek other jobs — rights theoretically guaranteed in the few countries that have ratified ILO conventions C97 and C143. ${ }^{31}$ Domestic servants who can change employers without losing their residence permits tolerate less exploitation and harassment at work and have more freedom to agitate and organize.

The reality of work situations reflects not only the laws but also their enforcement. Because few legal and organizational mechanisms support migrant domestic workers in the Gulf, women face an uphill battle with few allies and advocates. ${ }^{32}$ Sri Lankan nationals working in the Middle East can obtain assistance from their recruiting agency, the local police, or the Sri Lankan embassy or consular office in their country of residence. But in their search for profits, labor recruiting agencies may not prioritize worker welfare, and many guest workers feel that the local police and job agents are more likely to support their employers. ${ }^{33}$ And although they generally trust Sri Lankan diplomats to side with them, housemaids whom I have interviewed often find services at the embassy lacking (noting insufficient staff and Spartan accommodations). Rather than rely on formal institutions in times of trouble, women often turn to informal personal networks to help them out of difficult situations.

In sum, female domestic servants in the Gulf work long hours for low pay. Their live-in status, combined with local gender norms and familial expectations, constrain their sociability and mobility and limit their ability to separate home from workplace. Lack of legislation governing domestic service exacerbates this difficulty. In addition, other state and private institutions (for example, the police and the labor recruiting agencies) stack the deck against the migrant housemaid.

\section{Labor Dynamics in the GCC}

Hardship, injustice, and exploitation often lead to organized resistance, but this has not happened surrounding the issue of foreign migration from Sri Lanka. The micro-politics of women's work situations unfold against a backdrop of larger-scale labor dynamics in the GCC. The techniques of governance employed in host countries illuminate the relative lack of activism for Sri Lankan migrant workers in both host and sending countries.

The history of labor migration in the Gulf sheds light on why these labor-receiving countries employ harsh and effective techniques in governing migrants. Following the oil boom in the 1970s, guest workers flowed into the Gulf and their labor soon became a crucial aspect of local economies. In 1981, six states (Saudi Arabia, Kuwait, Bahrain, Oman, Qatar, and the UAE) formed the Gulf Cooperation Council. Estimates vary, but sources suggest that guest workers make up the majority of the population in many small GCC countries. ${ }^{34}$ Overall, foreigners make up 37 to 43 percent of the total population of the GCC countries and constitute 70 percent of the work force, with work force 
numbers significantly higher in the UAE (90 percent), Kuwait (82 percent), and Qatar (90 percent). ${ }^{35}$ The high percentage of "foreigners" worries government officials in these small countries. Even giant Saudi Arabia strives to control its guest worker population, which makes up 65 percent of its work force. ${ }^{36}$

Not only do guest workers make up significant percentages of GCC work forces, they also occupy less desirable positions. Most GCC countries have a de facto dual economy, with well-paying, non-strenuous state jobs held by "nationals" and low-paying labor jobs performed by foreigners. ${ }^{37}$ GCC governments have created public sector jobs with high wages and good benefits as a way to distribute oil wealth to their citizens. Foreigners, meanwhile, do the difficult, low-status jobs in the private sector. This situation has persisted for the past thirty years, but growth in the local population compounded with a halt in economic expansion and depletion of oil resources in certain countries, such as Bahrain, has created a need for change. ${ }^{38}$ Government administration can no absorb large numbers of the citizenry, but locals still expect public sector jobs. Citizens have begun to resent guest workers' private sector jobs, but they themselves do not wish to work under foreigners since such jobs would diminish their status and bring much lower rates of pay.

The number, economic importance, and potential political volatility of guest workers concerns state authorities in the Gulf. In the late 1980s, many states implemented "nationalization" policies to replace the foreign work force with citizens. ${ }^{39}$ These nationalization policies met with mixed results, succeeding in the public sector but not the private sector. In addition, GCC governments crafted legislation to minimize the "threat" that these foreigners pose to the "native" population. Strict regulations on length of stay, difficult-to-meet criteria for bringing in family members, the sponsorship system, inability to own land and businesses, and the near impossibility of obtaining citizenship all work to keep guest workers' stays short, temporary, or informal, and to minimize their ability to organize. ${ }^{40}$ Other circumstances also exacerbate the insecurity of migrant workers in the Gulf, including rampant discrimination, dependence on the whims of their sponsor, visa regulations that make staying in the country while changing jobs difficult, lack of legal rights, and the absence of unions. ${ }^{41}$ These techniques of governance have functioned to make guest workers physically useful but politically docile. ${ }^{42}$

Despite oppressive political structures, workers retain a degree of agency. People choose tactically whether to resist or accommodate to undesirable labor conditions, weighing the current situation against other needs and goals. Writing of male migrants, Khalaf and Alkobaisi argue that in the GCC countries, "Given the inferior political, legal, economic and social status of migrants, they have opted to accommodate instead of entering into conflict situations. ${ }^{43}$ Female migrants, with even fewer resources than male migrants and often with more pressing obligations at home, opt even more strongly for accommodation rather than confrontation. The policies of GCC governments effectively regulate foreign labor by keeping it temporary, docile, under control, and subject to deportation. These disciplinary structures strongly shape the choices individual migrants and their advocates make. The labor market in the Gulf, bifurcated with the broad distinction of citizen vs. guest worker, is further stratified according to gender, ethnicity, and nationality. These divisions undermine class solidarity by enhancing competition between other groups. Leonard writes, "Foreign workers are ranked by place or origin, receiving differential payment and treatment. ${ }^{, 44}$ Female domestic servants earn less than most other guest workers. In the UAE, for 
example, within the housemaid category, housemaids from the Philippines are paid more than those from Indonesia, Sri Lanka, Ethiopia, and Bangladesh in that order. ${ }^{45}$ Racial, ethnic, religious, and national stereotypes predetermine wages ${ }^{46}$ Regional affiliation also plays an important role in guest worker recruitment. Over the past twenty-five years, the GCC states have employed fewer non-GCC Arab workers (e.g., Palestinians, Jordanians, Egyptians, and Yemenis) and more Asians (e.g., Pakistanis, Indians, Bangladeshis, Sri Lankans, Filipinos, and Indonesians). ${ }^{47}$ Asians work for lower wages, leave their families at home, and are deemed (rightly or wrongly) by local governments to be less likely than co-ethnic Arab workers to engage in labor actions and spread radical ideas. ${ }^{48}$ Identity politics inextricably intertwine with labor relations in the Gulf, undermining interethnic solidarity by emphasizing fragmenting categories of allegiance.

Identity politics within host societies also provide a key context for understanding migration. In discussing situations of migrant housemaids, one must note the degree of gender empowerment in various labor-receiving countries. In many GCC countries, women and men have separate spheres and different entitlements. For example, Kapiszewski notes, "Just granting Saudi women the right to drive cars alone should result in removing around one hundred thousand foreign drivers from the labor force," which illustrates how gender norms influence labor opportunities and mobility situations for male guest workers and female nationals in Saudi Arabia. ${ }^{49}$ In most GCC countries, women are constrained in their freedom to socialize and move about, and few enter the work force. ${ }^{50}$ Migrant housemaids are similarly constrained as women. Based on evidence presented below on differences in organizing activities in the GCC, Asia, and Europe, I suggest that in combination with GCC labor disciplinary techniques, these gender roles curtail migrant women laborers’ ability to organize.

In sum, the GCC countries have extremely segmented labor markets, with the majority of workers coming from foreign countries and undertaking poorly paid, impermanent jobs in the private sector. Drawing on over thirty years of experience in regulating guest workers, GCC countries have developed effective techniques to control laborers' work, marginalize them from the dominant social structure, and reduce class solidarity across other categories of identity. These regulatory measures make labor organizing extremely difficult, particularly for migrant domestic workers.

\section{NGOs and Labor Unions in Sri Lanka}

I have argued above that women's work situations in their sponsors' homes abroad limit their potential to organize and that this disempowerment is reinforced by the larger governance structures by which the GCC regulates foreign guest workers. On the face of it, labor dynamics in receiving countries might appear to have little to do with activism in sending countries such as Sri Lanka. To the contrary, I argue that conditions in host countries directly influence migrant advocates' activities at home. In this section, I consider civil society and state organizations in Sri Lanka, examining the activities of NGOs, labor unions, and government institutions that support migrant workers. In subsequent sections, I argue that the activities of these Sri Lankan groups reflect transnational economic dynamics and the organizing climate in host countries.

Given the insecurity guest workers face while abroad, one might assume that vigorous labor organizations would arise in their home countries to protect their rights. But in Sri Lanka, despite the hard work and enthusiasm of the 
few activists who deal full time with migrant issues, civil society and the government have done surprisingly little for migrants. In stating this, I do not wish to denigrate the dedication and diligence of migrant labor advocates, only to point out that the several small organizations discussed below cannot and do not meet the organizing needs of Sri Lanka’s migrant workers, who number over a million strong.

Several NGOs in Sri Lanka focus on labor migration. The American Center for International Labor Solidarity (ACILS), based in a modest house on a residential street in Colombo, Sri Lanka's capital, lobbies for migrant issues, works directly with government departments to support multilateral agreements with other labor-sending countries, and funds partner organizations that help migrants directly with social and legal difficulties. ${ }^{51}$ In 1994 ACILS was instrumental in funding and establishing Migrant Services Center (MSC). With a staff number in the twenties, MSC ministers to worker needs and does advocacy work, lobbying, and campaigning. ${ }^{52}$ In 2005, MSC had twenty-six affiliated Migrant Workers Associations (MWAs) scattered around the country, with a total of fifteen hundred members. ${ }^{53}$ In addition to building leadership potential and dispersing information, the MWAs engage in activities such as reintegration and self-employment projects for returnees; savings, microcredit, and welfare schemes; the channeling of complaints from overseas workers to the SLBFE; and advocating for voting rights for citizens overseas.

Action Network for Migrant Workers (ACT FORM) is another Sri Lankan NGO that focuses on migrant issues. Partially funded by the ACILS, ACT FORM shares space with a feminist NGO in a suburban house and serves as an umbrella organization for other NGOs working on migration issues. ${ }^{54}$ Many of their constituents are the MWAs affiliated with MSC. ACT FORM is also affiliated with international migrant organizations, including the Philippines-based Migration Forum in Asia. ACT FORM publishes informational handbooks and a vernacular quarterly newsletter, Tharani, which is distributed to MWAs, overseas embassies, and a small group of current migrant workers abroad. ${ }^{55}$ ACT FORM also organizes events on migrants' human rights, prints informational posters, and runs press and electronic media campaigns. In addition, they occasionally consult with the Foreign Ministry and the SLBFE.

The International Organization for Migration (IOM) is a third NGO focused on migration issues. The Sri Lankan branch of IOM, based in a stately colonial-era home, does capacity building with the SLBFE and other government branches. ${ }^{56}$ True to their international missions, ACILS and IOM have hosted conferences to bring together labor ministers from Asian labor-sending countries to discuss mutual problems and come up with policy initiatives. ${ }^{57}$ ACILS organizers do not feel that the conferences have brought about significant policy changes at the governmental level, but the organizers feel that their efforts on this front have brought wider pressure from international organizations and local civil society to bear on policy-makers in Sri Lanka and encouraged multilateral consideration of migration issues.

During 2004, when I conducted interviews to assess the effectiveness of NGO services in Sri Lanka, those with whom I spoke — NGO workers, government officials, and migrants alike — uniformly expressed their disappointment with these organizations on a number of fronts. They note that the migration groups are relatively small, the NGO movement lacks cooperation and coordination, and the movement has not been able to influence the 
government on significant policy issues. ${ }^{58}$ In addition, barriers of language and locality hamper grassroots organizing. As one activist explained, class barriers have kept Colombo-based civil society groups from getting involved in migration issues most pertinent to unskilled rural women. ${ }^{59}$ The issue of class differences that divide Colombo intellectuals and activists from the less-educated workers from Sri Lanka's rural areas has arisen in numerous contexts. For example, Jayawardena and de Alwis suggest that the accusations that Colombo women's organizations are led by Westernized, middle-class feminists who do not connect with local traditions and values are a backlash against feminist ideals. ${ }^{60}$ Although I agree that one must examine the politics behind such a criticism, the gaps in world view, language, and locality between organizers and their intended constituents are clear, and these shortcomings undermine NGO labor organizing activities.

Like Sri Lankan NGOs, local labor unions have not taken up migrant issues with vigor — this despite the fact that Sri Lanka has a long history of labor organizing in other spheres, with unions organizing first against the colonial regime's labor extraction techniques in the plantation sector and then against post-independence governments and business entities. ${ }^{61}$ Sri Lankan NGOs that advocate for migrant workers, such as ACILS and MSC, are nominally affiliated with local unions, ${ }^{62}$ but NGO activists note that their union allies , pay lip service to migrant issues but have not participated in related initiatives ${ }^{63}$ In addition, some strong unions, such as the plantation unions, are for historical reasons more concerned with the high prestige, masculine sphere of politics than with relatively lowprestige sphere of labor issues. ${ }^{64}$ Showing solidarity with transnational domestic workers, even with women migrants from the plantation community, has not been a visible priority. Even the few garment factory unions that do recognize women's issues focus their attention on labor relations in Sri Lanka's Free Trade Zones. ${ }^{65}$ The relative lack of union attention to "women's issues" or domestic service, whether in Sri Lanka or abroad, no doubt reflects local gender relations, the difficulty of organizing workers isolated in separate houses, and cultural norms and values that obscure domestic service as a form of labor.

Despite the general paucity of activism around migration, the NGOs concerned with the issue $d o$ agitate for change. Recognizing the importance of raising political consciousness around migration, in early 2004 ACILS, MSC, ACT FORM, and some affiliated NGOs and unions lobbied the government to provide a way for Sri Lankan citizens working abroad to vote in local elections. Earlier, in 1996, Sri Lanka had ratified the United Nation's International Convention on the Protection of Rights of All Migrants and Their Families (1990). This came into force in July 2003, when the twentieth world nation ratified the convention. Of interest for this discussion is the clause in the Convention giving migrant workers the right to absentee ballots while working abroad. Advocates felt that drawing attention to voting arrangements would raise the issue of citizens' rights. ${ }^{66}$ By 2005 , however, no government action had taken place on this front. In contrast, Kyoko Shinozaki suggests that the Philippine state instituted absentee voting for Overseas Contract Workers in 2003 as part of its effort to increase migrants' sense of national identity and belonging. ${ }^{67}$ If Sri Lankan migrants voted while abroad, perhaps migrant workers associations would have more clout with politicians. And migrants' issues, particularly those of migrant domestic servants, might become significant campaign items. Here again, lack of forward movement on an important migrant issue proves puzzling — unless global economic issues and the organizing climate in the GCC are taken into account. 
Government critiques of the way that the NGO movement and labor unions have dealt with migrant workers' problems highlight structural barriers at the national and international level. For example, L.K. Ruhunage, in 2004 the employment and welfare counselor at the Sri Lankan Consulate in Dubai, contends that unions and NGOs can be of little practical help to migrants. Jurisdiction, Ruhunage explained, is one contributing factor: local NGOs and labor unions have no authority to settle disputes that arise in foreign countries; the SLBFE and the consular offices have to take care of such situations. This official asserted that even international human rights organizations turn first to the Sri Lankan Consulate to investigate and clear up problems. Ruhunage concluded that labor unions and NGOs had little authority abroad, and saw this lack of effective agency as a reason that these groups dealt only tangentially with migrant issues.

The Sri Lankan government, then, seems to have a monopoly on the ability to administer to migrant labor. In addition to the administrative apparatus, the government would seem to have a strong economic and social motivation to support its citizens overseas. Migrant remittances provide valuable foreign exchange, and the protection of vulnerable housemaids and the families they leave behind receives a fair share of media attention and

forms the basis for nationalist political rhetoric. ${ }^{68}$ Migrant issues have seized the popular imagination, which makes the lack of government will to strengthen support for migrants all the more puzzling.

\section{Sri Lankan Politics and Diplomatic Activities to Support Migrant Workers}

A discussion of the lack of NGO and union activities has led inexorably back to the state. If the government indeed holds the sole power to ameliorate migrant workers' unstable employment situations abroad, why has it not done more in their behalf? I argue that government inaction reflects three main factors: Sri Lankan gender norms, women's lack of participation in national politics, and (above all) Sri Lanka's disadvantageous position in the international division of labor.

Lack of government focus on migrant housemaids mirrors the dearth of women and women's issues in Sri Lanka politics. One might think that national politics would favor women: women have voted actively in Sri Lanka since 1931 (as long as men have), and Sri Lanka elected a woman prime minister in 1960 and a women president in $1994 .{ }^{69}$ In addition, women nearly equal men in educational qualifications. ${ }^{70}$ But despite the fact that women vote regularly and enthusiastically in elections, they make up only a very small fraction of elected legislative representatives, ranging from 2 to 5 percent. ${ }^{71}$ Women vote, but they do not usually run for office. As in the rest of South Asia, women enter politics primarily through family connections, especially after the assassinations or deaths of their fathers or husbands. Although women receive respect once they obtain office, harassment, character slurs, and social restrictions on contact with strange men keep most women out of political campaigns and thus keep women's issues out of the political arena. There are few female legislative representatives and, except on International Women’s Day, little political discussion of “women’s issues” or female migration. union activities focus on “women's issues” or domestic service.\} Similarly, despite educational qualifications, women still lag behind men in employment, particularly in professional and managerial positions in both the public and the private sphere. ${ }^{72}$ Women activists struggle against all these barriers, but in spite of the dedicated efforts of NGO leaders, the feminist movement remains small and marginal in Sri Lanka. or they have little to show for their efforts: strong 
organizations can have little success at times, no? Is this better? $\}^{73}$ Thus women and women's issues play only a marginal role in Sri Lankan politics.

Even though women's issues have not dominated state policy on the social front, migration is of paramount importance for the nation's economy. In its state-to-state interactions with host countries in the Gulf, the government of Sri Lanka has historically balanced the interests of its laborers for higher wages and better working conditions against the need to maintain favorable diplomatic relations with a major source of employment. As a debtor and a developing nation, Sri Lanka has a little status and power in the international hierarchy of nations and its diplomats operate within these preexisting power relations when crafting intergovernmental arrangements and protecting its citizens abroad.

Just as migrants accommodate to their labor conditions in the Gulf for fear of losing their jobs, Sri Lankan government officials in many cases accommodate to the wishes of the more powerful GCC governments for fear of losing valuable employment opportunities for its citizens. For example, in 2008 the Sri Lankan government negotiated a new minimum wage of US\$180 a month for housemaids working in Kuwait. ${ }^{74}$ But Sri Lankan government officials are also tasked with enhancing economic relations with labor-receiving countries in the Gulf a goal that can conflict with the protection of workers' rights. For example, in 1998 four representatives from the SLBFE visited consular offices in Kuwait and the UAE. The following extract from a discussion of the aftermath of a labor dispute at Atraco Industrial Enterprises in the UAE illustrates the conciliatory attitude of the Sri Lankan officials:

Very recently, a large number of factory workers were sent to Sri Lanka as they struck work demanding the removal of certain officers attached to the management of the factory. We had a discussion with the management of the factory and informed them that the purpose of our visit was to study labour requirement [sic] of the factory and the shortcomings of our labour. The management was very satisfied with the labour provided by Sri Lanka. However, they had a reservation on the behavior of some of our employees. Notwithstanding the problems they assured continuation of using our labour and we gave an undertaking to send more disciplined workers in future. ${ }^{75}$

The delegation also found workers' complaints from another factory "baseless." ${ }^{\text {,76 }}$ The content and tone of this report suggest that in future cases as in this one, Sri Lankan officials may hesitate to take up the labor cases of overseas workers, preferring instead to cement relationships with factory owners and employers. More generally, government representatives from labor-sending countries worry that if they support their guest worker population, a host country could hire laborers from elsewhere. ${ }^{77}$

Government officials have stepped in to help Sri Lankan workers when they have run into trouble abroad and diplomatic missions regularly aid stranded workers and support their citizens in court. In the Gulf countries Sri Lankan welfare officers and labor attachés have taken up workers' causes with employers, job agents, and the police. But Sri Lankan embassies and consular offices face a numerous challenges - including the understaffing of diplomatic offices — in doing so. ${ }^{78}$

In 2004, I visited the Sri Lankan Consulate in Dubai and shadowed its employment and welfare counselor, L.K. 
Ruhunage, for a week on his official rounds to job agencies, garment factories, police stations, the jail, the consular safe house, and the airport. This experience provided insights into the challenges of diplomatic work. As we traveled to the Free Trade Zone in Ajman, Ruhunage remarked that the Sri Lankan consulate in Dubai needed one more diplomatic officer or labor welfare officer to handle correspondence and make field visits; at that time, only two field officers covered six emirates (Abu Dhabi having an embassy of its own). ${ }^{79}$ Ruhunage suggested that the UAE limited the number of diplomats a country could place in its foreign mission. In addition, maintaining diplomats abroad is costly, particularly if a mission does not generate any income.

Even with additional staff, Ruhunage argued, the Dubai consulate would not be able to enforce labor conditions and wages for Sri Lankan workers. Enforcement rights lay instead with the government of the UAE. The Sri Lankan diplomats who handled labor issues could represent the interests of their citizens, but they had no official authority to inspect worksites and enforce standards. Instead, local labor officials held this authority. In Ruhunage's opinion, the UAE did not employ enough people to monitor the situations of its many guest workers. In addition, the Sri Lankan consular office covered accommodation for stranded workers; despite benefiting from cheap foreign labor, the UAE government bore no responsibility in such cases. In short, embassies and consular offices could bring only a limited number of staff into a host country, and the staff had only limited authority over local labor conditions. Bilateral agreements in place between Sri Lanka and the UAE have allowed Sri Lankan diplomats to point out problems when high-ranking officials met. But Ruhunage suggested that if the Sri Lankan consular office complains extensively, the UAE would suggest that they either stop sending workers or adjust to the current situation. Ruhunage thought that emphasis on labor issues needed to take place in other venues, including seminars, regional meetings, and academic research.

Activists and civil servants whom I interviewed agreed that the state apparatus (including embassies, consular offices, and governmental departments in Sri Lanka) could better serve migrants by providing additional informational coordination between various ministries in Sri Lanka, between the SLBFE and the Sri Lankan embassies abroad, and between embassies of other labor-sending countries.$^{80}$ Hampered by lack of money and staff, and constrained by the laws of the receiving countries, governments of labor-sending countries in weak economic and political positions often fail to exert effective diplomatic pressure to protect the rights of their citizens. ${ }^{81}$ Given all of the conditions described above it is fair to wonder whether any Sri Lankan organization can effectively apply pressure to improve the lot of migrant laborers. The preceding discussion of NGOs, labor unions, government initiatives, and diplomatic missions suggests a pervasive lack of political will and practical authority. Are states and civil society organizations in all migrant-sending countries equally hampered? If not, why not? What factors disproportionately disempower Sri Lankan organizations? The answer lies, I argue, not within Sri Lanka but in the nations where Sri Lankan migrants work. I illustrate this point with the following two comparisons: the first between labor organizing climates in the GCC, Asia, and Europe, and the second between migration in Sri Lanka and the Philippines. 


\section{Labor Relations Compared: Organizing Climates in the GCC, Asia, and Europe}

As the activities of ACILS, MSC, and ACT FORM show, labor activism and political agitation for migrant workers' issues is ongoing in Sri Lanka, but on a muted scale. The situation is even worse in the GCC — and, as I will argue here, inactivity in these two spheres is interconnected. In contrast to the situation in the GCC, organizing activities face less resistance in Europe and certain destination countries in East Asia. Staunch activism in countries that send labor to European and Asian destinations reflects these more favorable organizing climates. In this section, I explore labor relations in a series of these destinations.

GCC government policies limit organizational activity. GCC countries have strict rules about civil society organizations established by their own citizens, not to mention those organized by guest workers, and they deport “troublesome” foreigners. Although the GCC governments generously grant their citizens many social welfare benefits (free education and health care; subsidized housing, water, and electricity; and well-paid government jobs with pensions and benefits), political rights have not kept pace. Khalaf notes, "Political life in the societies of the Gulf lacked and continues to lack the institutions of democratic representation.” ${ }^{22}$ For example, the Bahrain Centre for Human Rights lent help to migrants until its director was arrested in September 2004 for criticizing the government. $^{83}$ Volunteers reorganized, and the Society for the Protection of Migrant Workers' Rights received a license to operate in December 2004. ${ }^{84}$ Other GCC countries are even stricter than Bahrain. In Dubai, “foreign” residents can organize “cultural” groups, but these cannot instigate political actions. ${ }^{85}$ Because of the generous social benefits, local people support their governments even though they are not democratic or participatory. For foreign guest workers (who do not receive the same largess from the state) local political conditions limit opportunities for social organization or protesting work conditions.

In contrast to the Middle East, the organizing climate in Hong Kong and Singapore is more liberal. In addition, gender roles in these states are less restrictive for women. Although the state limits migrants' rights in many ways, Hong Kong offers foreign domestic workers a legislated (but still sub-poverty) minimum wage that, at US\$470 a month, is nearly four times the going rate in the GCC countries. ${ }^{86}$ Further, Hong Kong has various governmentally enforced contract requirements such as rest days, annual holiday, sick leave, and insurance protection. Moreover, Hong Kong has a political environment conducive to labor organizing: "Hong Kong has a vibrant civil society populated by lively labour unions, NGOs, media, religious groups and other organizations. ${ }^{\text {} 87}$ Wee and Sim argue that Hong Kong differs from many other labor-receiving countries in that it is "capitalist, liberal and governed by the rule of law." ${ }^{88}$ This organizing climate enables the empowerment of Filipinas, who for many years have dominated the domestic service market in Hong Kong. ${ }^{89}$ Indeed, the majority of the migrant labor organizations are "founded, staffed, catalysed or led by Filipinos.”90

Singapore has a strong state and a weaker civil society, thus political organizing there is less vigorous than in Hong Kong. NGOs focus on service work rather than policy and "stay clear of human rights issues for fear that such advocacy work may be misconstrued as being 'political." "91 The government of the Philippines has intervened in labor relations, even temporarily banning Filipina domestic workers from going to Singapore in response to public outcry in the Philippines over the Flor Contemplacion case where a Filipina worker was sentenced to death in 
Singapore. Consequently, workers from Indonesia, where the government is less interventionist, have become more popular with Singapore job agencies and employers. ${ }^{92}$ Indonesian domestic workers have fewer rest days and lower starting wages than Filipinas, but are now joining forces with Filipina-led NGOs in a growing show of transnational labor solidarity. ${ }^{93}$ These encouraging developments suggest that in favorable labor-organizing climates, domestic workers can and will organize, even across national lines to improve their situations.

Although better than the conditions in the Middle East, the situations in Singapore and Hong Kong compare unfavorably to the conditions in the European Union. For example, Leah Briones, who studies migration from the Philippines to Hong Kong and to Europe, notes that Filipina women consider themselves better off working "illegally” in Paris than working legally in Hong Kong because Paris has a more liberal civil society. ${ }^{94}$ Similarly, Sri Lankans now seek jobs in Italy, preferring them to jobs in the Gulf. Migrant women prefer jobs in Europe not only for greater political freedoms but also for higher salaries. For example, Jacqueline Andall reports that live-in care work for the elderly pays between 500 and 900 euros a month in Italy. ${ }^{95}$ Ecuadorian domestic workers in Madrid could make as much as 550 euros a month; lack of worker documents, along with the provision of food and lodging, explains the lower wages in Spain. ${ }^{96}$ Au pairs in Germany can make 205 euros a week. ${ }^{97}$ In Germany, migrant domestic workers made between eight and ten euros an hour for cleaning and five to eight euros for child care; au pairs and live-ins earned less than live-out domestic workers with a larger circle of clients. ${ }^{98}$ These wages compare favorably to the 100 to 125 dollars (65 to 80 euros) a month that Sri Lankan migrants report earning in the Gulf. Wages and organizing conditions in various countries and regions correlate closely with migrants' valuations of jobs in these locations. Sri Lankan workers consider jobs in Singapore and Hong Kong much more desirable than jobs in the Middle East, and they value jobs in Europe most highly of all. They note, however, that agency fees for jobs rise in direct proportion to job desirability, with jobs in Europe (even illegal ones) unaffordable for most migrants, at least on their first journey abroad. Similarly, Filipina domestic workers often see Hong Kong as a steppingstone for moving on to Israel, Canada, and the EU. ${ }^{99}$ These data suggest that workers value jobs in destinations that offer higher pay, greater labor protections, and more autonomy.

\section{Assessing Activism: A Comparison between Sri Lanka and the Philippines}

The evidence above suggests that organizing climate in labor-receiving countries clearly influences the degree of guest worker labor activism. Asian and European destination countries provide more protection for migrant workers than do Middle Eastern countries. ${ }^{100}$ Workers in Europe are more likely to organize than are those in Hong Kong and Singapore, with workers in the Middle East the least likely of all to organize. Does the degree of organization allowed in destination countries also correspond with organizing activity in the migrants' the sending countries? Evidence suggests that in addition to shaping migrants' career trajectories, situations in host countries influence people's behaviors at home. When worker initiatives (such as those organized by Filipinas and Indonesians in Hong Kong) and government activities (such as the Philippine intervention in Singapore) result in better working conditions, people are encouraged to organize and protest for their rights. In contrast, when the host government represses such initiatives (such as in the GCC), laborers face adversity by accommodating to difficult circumstances instead of seeking to challenge or change. In cases in which the larger social structures make protest difficult or 
fruitless, workers find it difficult and dangerous to organize; and labor unions, NGOs, and sending-country governments are also hampered in supporting migrants. In short, the larger structures in host countries constrain the changes people can envision making, either limiting or encouraging activities at home.

To illustrate this point, consider the relative paucity of organizing going on in Sri Lanka (discussed above) in light of the rich and energetic organizing done by Filipinas in the Philippines and in a variety of labor-receiving countries. According to Maruja Asis, in 1997 thirty-eight migrant worker organizations were operating in the Philippines. ${ }^{101}$ In addition, Filipina domestic workers have organized a number of NGOs and labor unions in Hong Kong. ${ }^{102}$ In Taiwan and Singapore they organize around churches. ${ }^{103}$ Filipinas are thus active in a wide range of organizations in their home and host countries.

A number of unique factors have doubtless shaped the organizing trajectories of migrants from Sri Lanka and the Philippines. Significant among them, I hypothesize, are the political and personal freedoms that workers experience in the labor-receiving countries. The size, scale, and history of migration; degree of migrant education; and gender roles and norms are also influential.

To understand the role of host country organizing climates on sending-country labor activism within the comparative framework proposed here, significant differences in the destination countries of Sri Lankan and Filipina transnational domestic workers must be noted. Nearly 90 percent of Sri Lanka’s migrant women work in West Asia (particularly Saudi Arabia, Kuwait, the UAE, Qatar, Lebanon, and Jordan). ${ }^{104}$ In contrast, Filipino women work in diverse locations around the globe, with only 30 percent going to the GCC (Saudi Arabia, UAE, and Kuwait), 60 percent going to countries in East and Southeast Asia (especially Hong Kong, Japan, Taiwan, and Singapore), and another 6 percent going to Europe (especially Italy and the United Kingdom). ${ }^{105}$ Thus Filipinas predominantly work in states in East and Southeast Asia that give more chance for autonomous activities (socializing, moving around unsupervised) and are more conducive to labor organizing than the Middle East. ${ }^{106}$

The size and scale of the migrant flows from Sri Lanka and the Philippines also differ. In 2002, over twice as many migrant women left the Philippines (over 300,000) than left Sri Lanka $(133,251) .{ }^{107}$ With an estimated stock of 7.9 million overseas contract workers in 2003 and an estimated population of roughly 82.7 million, nearly 10 percent of the population of the Philippines worked abroad. ${ }^{108}$ In contrast, in 2002 Sri Lanka's total of 1 million overseas workers and its population of roughly 19.3 million people meant that a little over 5 percent of the population was employed abroad. ${ }^{109}$

Educational qualifications also make a difference. E.P. Thompson has decisively illustrated that the working class can generate leaders on its own without recourse to the bourgeois intellectuals that Marx assumed would spearhead the revolution. ${ }^{110}$ Nevertheless, I include data on migrant education in hopes that the years people spend in school are of some practical use. The Philippines economy cannot absorb all its college graduates who enter the migrant labor market in search of jobs. Thirty-two percent of Filipina migrant domestic workers go to Hong Kong; Wee and Sim note that in 2001, 62 percent of them had received some tertiary education. ${ }^{111}$ Similarly, a large majority of Filipinas entering Canada through the Live-in Caregiver Program had bachelor degrees or non-university diplomas. ${ }^{112}$ One researcher noted that most of her Filipina interviewees had post-secondary training. ${ }^{113}$ In contrast, 
a Sri Lankan survey found that less than 3 percent of Sri Lanka’s housemaid returnees after the 1990 Gulf War had passed their A-level (end of high school) exams. ${ }^{114}$ Most Sri Lankan migrant housemaids have only six to nine years of education. ${ }^{115}$ Despite high numbers of unemployed female university graduates, educated Sri Lankan women continue to refuse to take on the low-status job of housemaids. ${ }^{116}$ These significant educational differences between Filipina and Sri Lankan migrant women may in part account for the greater labor agitation among Filipinas.

The history of migration may also play a role in levels of labor activism. Filipino laborers have been migrating since the early twentieth century. ${ }^{117}$ In contrast, Sri Lankan labor migration began in earnest more recently — in the mid 1970s. The longer the period of migration, the savvier and better organized the laborers. For example, Constable reports that Filipina migrant activists have become more visible and vocal in Hong Kong over the past ten years, and are now affiliating with newly arrived migrants from Indonesia. ${ }^{118}$ Similarly, the second generation of Sri Lankan migrants seems poised to migrate in a new way: compared to the earlier generation of married Sri Lankan women working in the Middle East, among the current twenty-somethings, more unmarried migrants (male and female) are going abroad, and they seek better jobs in more liberal destination countries. ${ }^{119}$ I argue that the levels of labor activism in the Philippines and Sri Lanka reflect the length of time that people from both countries have been migrating. It takes time for people to build networks of kin, acquaintances, co-ethnics, and other allies in destination countries to facilitate migration, share local knowledge, and provide security in case of difficulties. Future research could fruitfully explore whether Sri Lankan migration will transform as Philippine migration already has, with more educated, mobile migrants heading to "better" destination countries, where a politicized group of activists may voice sophisticated critiques of global capitalism.

To summarize this comparison, a greater proportion of the Philippines population works overseas, over twice as many women migrate from the Philippines as from Sri Lanka, Filipina domestic servants have higher educational qualifications than Sri Lankans do, and two thirds of them go to places where protest, though difficult, is more possible than in the Middle East. More (and more educated) Filipina migrants have worked longer in destination countries that offer more relative freedom, leading to more organizing activity. I argue that these factors in large part explain the greater NGO activity in the Philippines as compared to Sri Lanka.

\section{Conclusion}

In this article, I have argued that political freedoms in destination countries have a significant effect on organizing activities within those host nations. Comparing the Sri Lankan and Philippine situations, I contend that the vibrant activism in the Philippines correlates with the liberal organizing climates in the EU and in East and Southeast Asia, while the paucity of organizing in Sri Lanka correlate with the strict repression of guest workers in the GCC. Nevertheless, although the Philippines has greater government activity and the highest number of migrant NGOs among labor-sending countries in Asia, activists feel that the government and civil society efforts have still not sufficed to protect migrants adequately. ${ }^{120}$ This raises the question of what factors hamper even the more proactive sending-country governments in their advocacy for migrant citizens. Economic evidence suggests that labor-sending countries are rarely in a strong position to influence guest worker labor conditions even in liberal, organizationfriendly host countries. The institutions with the most power to protect Sri Lankan migrant workers are the 
governments in GCC countries — bodies that benefit from cheap, exploitable labor, and have no democratic obligations to these foreign nationals. This reflects the existing hierarchy among nations; it also reflects the expectation that a sovereign nation will regulate its own labor market and labor laws - an expectation that persists despite the increasingly transnational character of labor. Given the structures impeding civil and state representatives from interceding in favor of migrant laborers, the paucity of labor activism in Sri Lanka no longer seems so puzzling.

Since the inception of the discipline, anthropologists have argued about the relationship between the individual and society. Scholars ask how much agency actors have to resist and transform social structures. ${ }^{121}$ The data presented here reveal the reasons that unions, NGOs, and politicians in Sri Lanka have not succeeded, despite the wholehearted efforts of well-meaning individuals, in their efforts to support migrant laborers. From whence, then, can change originate for Sri Lankan migrants, particularly given the strict political venue of the GCC? The weakness of labor-sending countries to protect their laborers highlights the need for two regulatory mechanisms: multilateral agreements between labor-sending countries about minimum contract elements and an international mechanism for enforcing standards and conditions. But states weigh the benefits of multilateral cooperation against the fear that by requesting improvements for their migrants they will lose their share of the guest worker market to other nations.

Having tried earnestly but inadequately to support and advocate for migrant laborers, migrant workers and activists alike point to the Sri Lankan government's responsibility to protect its citizens working abroad. But key consular staff members, such as Ruhunage, felt that they did not have the powers to do their job adequately, shifting responsibility toward local officials in the GCC. I saw a certain irony in the fact that when I tracked down Ruhunage, the one person most Sri Lankans would hold responsible for bettering labor conditions in the UAE, he in turn suggested that change needed to spring from seminars, meetings, and academic research. Instead of merely reporting on and assessing labor activism, I find my work now called to do some of the heavy lifting, providing a venue for voicing priorities related to neoliberal economic policies, labor issues, gender discrimination, and human rights. Repressive structures in the GCC, combined with a dearth of international regulatory devises and a disadvantageous division of international labor, leaves migrants, activists, government servants, and scholars alike facing an uphill battle to support and defend migrant workers.

ACKNOWLEDGMENTS: Funding for this research was provided by grants from the American Institute for Sri Lankan Studies (AISLS), Portland State University, the Oregon Council for the Humanities, and the National Science Foundation. Special thanks are due to Mr. M.M. Deshapriya at the SLBFE for his help with statistical data. Prior versions of this paper was presented at the American Anthropological Association's annual meeting in 2005, the Social Science Research Council's International Conference on "Inter-Asian Connections” in Dubai, United Arab Emirates in 2008, and at the conference "G.C.C. - Gender, Connectivity, and Change in the Gulf Arab States” at the University of California, Irvine in 2008.

\section{References}

ACT FORM. 2003a. Tharani: Newsletter of the Action Network for Migrant Workers (ACT FORM). First quarter. Ratmalana: Navamaga Printers. 
_. 2003b. Tharani. Second quarter. Ratmalana: Navamaga Printers.

—. 2004. Handbook for Migrant Workers (Sinhala-language publication). Colombo: ACT FORM.

Addleton, Jonathan S. 1991. The impact of the Gulf War on migration and remittances in Asia and the Middle East, International Migration 29 (4): 509-26.

Afsar, Rita. 2005. Conditional mobility: The migration of Bangladeshi female domestic workers. In Huang et al., eds. 2005. 115-45.

Andall, Jacqueline. 2005. Change and continuity in the Italian domestic work sector. Paper presented at the conference “Migration and Domestic Work in Global Perspective,” 26-29 May 2005. The Netherlands Institute of Advanced Studies, Wassenar.

Anderson, Bridget. 2002. Just another job? The commodification of domestic labor. In Ehrenreich and Hochschild, eds. 2002. 104-14.

Asis, Maruja M.B. 2005. Caring for the world: Filipino domestic workers gone global. In Huang et al., eds. 2005. 21-53.

Bass, Daniel. 2004. A place on the plantations: Up-country Tamil ethnicity in Sri Lanka. PhD diss. (Department of Anthropology, University of Michigan).

\{Briones, Leah. Personal communication\} \{Do I need a fuller reference here?\}

Chang, Grace. 2000. Disposable domestics: Immigrant women workers in the global economy. Cambridge, Mass: South End Press.

Collier, Jane, and Sylvia Yanagisako. 1987. Toward a unified analysis of gender and kinship. In Jane Collier and Sylvia Yanagisako, eds. Gender and kinship: Essays toward a unified analysis. Palo Alto, Calif:: Stanford University Press. 14-50.

Conklin, William. 2004. Interview. 5 February 2004. American Center for International Labor Solidarity. Colombo, Sri Lanka.

Constable, Nicole. 2002. Filipina workers in Hong Kong homes: Household rules and relations. In Ehrenreich and Hochschild. 2002. 115-41.

- 2007. Maid to order in Hong Kong: Stories of migrant workers. 2d ed. Ithaca, N.Y.: Cornell University Press.

\{----. 2008. Not sure of title. I want to reference Nicole's article that is part of the 9-paper submission Nicole Constable sent in. Not sure what the new title is; not sure whether her article is in 'this volume' or the prior CAS volume. Please help! Thanks!\}

Decena, Carlos Ulises, Michele G. Shedlin, and Angela Martinez. 2006. Los hombres no mandan aqui: Narrating immigrant genders and sexualities in New York. Social Text 24 (3): 36-54. 
DGMF (Deputy General Manager [Finance]). 1998. Report on the study tour made by the delegation to Kuwait and United Arab Emirates (September 20 ${ }^{\text {th }}-$ September $30^{\text {th }}$ 1998). Sri Lankan Bureau of Foreign Employment. 6 October. Photocopy.

Escobar, Arturo. 1988. Power and visibility: Development and the invention and management of the third world. Cultural Anthropology 3(4): 428-43.

Ehrenreich, Barbara, and Arlie Russell Hochschild. 2002. Global woman: Nannies, maids, and sex workers in the new economy. New York: Metropolitan/Owl Books.

Fernando, KODD. 2004. Interview. 14 January. Deputy general manager information technology, Sri Lankan Bureau of Foreign Employment. Colombo, Sri Lanka.

Financial Times Information. 2004. Migrant worker rights group gets licence in Bahrain. Financial Times Information. http://web.lexis-nexis.com/universe/document?_m=38e988085ba38a4b 127a5b6e11774822\&_docnum=7\&wchp=dGLbVtz-zSkVA\&_md5=342df4a4cb939afd936cd73 3496c1157. Posted 31 December 2004. Accessed 27 February 2005.

Frank, Andre Gundar. 1966. The development of underdevelopment. Monthly Review 18: 17-31.

Freeman, Carla. 2001. Is local: global as feminine: masculine? Rethinking the gender of globalization. Signs 26 (4): 1007-37.

Foucault, Michel. 1979. Discipline and punish. New York: Vintage.

Gamburd, Michele. 2000. The kitchen spoon's handle: Transnationalism and Sri Lanka's migrant housemaids. Ithaca, N.Y.: Cornell University Press.

_ 2005. Lentils there, lentils here: Sri Lankan domestic labour in the Middle East. In Huang et al., eds. 2005. 92-114.

2008. Milk teeth and jet planes: Kin relations in families of Sri Lanka’s transnational domestic servants. City and Society 20 (1): 5-31.

\{Gardner, Andrew. Personal communication\} \{Do I need a fuller reference here?\}

Gledhill, John. 2007. Neoliberalism. In David Nugent and Joan Vincent, eds. A companion to the anthropology of politics. Oxford: Blackwell Publishing. 332-48.

Goonasekere, Savitri. 2002. Constitutions, governance and laws. In Swarna Jayaweera, ed. Women in postindependence Sri Lanka. New Delhi: Sage. 41-78.

Gunatillake, Godfrey, and Myrtle Perera, ed. 1995. Study of female migrant worker [sic]. Colombo: Marga Institute (Sri Lanka Centre for Development Studies), World Bank, and Ministry of Policy Planning and Implementation. Harrison, Faye V. 1997. The gendered politics and violence of structural adjustment. In Louise Lamphere, Helene Ragone, and Patricia Zavella, eds. Situated lives: Gender and culture in everyday life. New York: Routledge. 451- 
68.

Hess, Sabine. 2005. Big sisters are better domestic servants?! Au pair as live-in domestic work. Paper presented at the conference "Migration and Domestic Work in Global Perspective," 26-29 May 2005. The Netherlands Institute of Advanced Studies, Wassenar.

Hewamanne, Sandya. 2008. Stitching identities in a free trade zone: Gender and politics in Sri Lanka. Philadelphia: University of Pennsylvania Press.

Shirlena Huang, Brenda S.A. Yeoh, and Noor Abdul Rahman, eds. 2005. Asian women as transnational domestic workers. Singapore: Marshall Cavendish.

Hugo, Graeme. 2005. Indonesian international domestic workers: Contemporary developments and issues. In Huang et al., eds. 2005. 54-91.

Human Rights Watch. 2007. Exported and exposed: Abuses against Sri Lankan domestic workers in Saudi Arabia, Kuwait, Lebanon and the United Arab Emirates. New York: Human Rights Watch.

2008. "As if I am not human”: Abuses against Asian domestic workers in Saudi Arabia. New York: Human Rights Watch.

ILOLEX. 2005. Database of International Labour Standards. http://www.ilo.org/ilolex/english/conv disp1.htm. Geneva: ILO. Updated 17 March (accessed 25 November 2005).

Institute of Policy Studies (IPS). 2004. Sri Lanka: State of the economy 2004. Colombo: Institute of Policy Studies. Iredale, Robyn. 2003. Asian labour ministerial consultations, Sri Lanka, 1-3 April 2003: International labour migration in Asia: Trends, characteristics, policy and interstate cooperation. Colombo: International Organization for Migration.

Jayawardena, Kumari. 1973. The origins of the left movement in Sri Lanka. Colombo: Sanjiva Books.

Jayawardena, Kumari, and Malathi de Alwis. 2002. The contingent politics of the women’s movement in Sri Lanka after independence. In Swarna Jayaweera, ed. Women in post-independence Sri Lanka. New Delhi: Sage. 245-77. Jayaweera, Swarna. 2002a. Fifty years since political independence: An overview. In Swarna Jayaweera, ed. Women in post-independence Sri Lanka. New Delhi: Sage. 15-40.

- 2002b. Women in education and employment. In Swarna Jayaweera, ed. Women in post-independence Sri Lanka. New Delhi: Sage. 99-142.

Jayaweera, Swarna, Malsiri Dias, and Leelangi Wanasundera. 2002. Returnee migrant women in two locations in Sri Lanka. Colombo: Cenwor.

Kapiszewski, Andrzej. 2006. Arab versus Asian migrant workers in the GCC countries. Paper presented at the "United Nations Expert Group Meeting on International Migration and Development in the Arab Region.” United Nations Secretariat. Beirut, Lebanon, 15-17 May. 
Khalaf, Sulayman N. 1992. Gulf societies and the image of unlimited good. Dialectical Anthropology 17: 53-84. Khalaf, Sulayman, and Saad Alkobaisi. 1999. Migrants' strategies of coping and patterns of accommodation in the oil-rich Gulf societies: Evidence from the UAE. British Journal of Middle Eastern Studies 26 (2): 271-98.

Lan, Pei-Chia. 2003. Negotiating social boundaries and private zones: The micropolitics of employing migrant domestic workers. Social Problems 50 (4): 525-49.

- 2005. Surrogate family, disposable labour and stratified others: Transnational domestic workers in Taiwan. In Huang et al., eds. 2005. 210-32.

—. 2006. Global Cinderellas: Migrant domestics and newly rich employers in Taiwan. Durham, N.C.: Duke University Press.

Leonard, Karen. 2003. South Asian workers in the Gulf: Jockeying for places. In Richard Warren Perry and Bill Maurer, eds. Globalization under construction: Governmentality, law, and identity. Minneapolis: University of Minnesota Press. 129-70.

\{Liebelt, Claudia. I want to reference Claudia's article that is part of the 9-paper submission Nicole Constable sent in. Not sure what the new title is; not sure whether her article is in 'this volume' or the prior CAS volume. Please help! Thanks!\}

Longva, Ahn Nga. 1997. Walls built on sand: Migration, exclusion, and society in Kuwait. Boulder, Colo.: Westview Press.

Looney, R.E. 1992. Manpower options in a small labour-importing state: The influence of ethnic composition on Kuwait’s development. International Migration 30 (2): 175-200.

\{Delete this citation\} Lutz, Helma and Susanne Schwalgin (CHECK CITATION ON THIS.)

\{Tom: Here's the new Lutz citation. The formatting is wonky; I'll let you figure out how to fix it! (-) Lutz, Helma. 2008. "When Home Becomes a Workplace: Domestic Work as an

Ordinary Job in Germay?" In Migration and Domestic Work: A European

Perspective on a Global Theme. Burlington, VT: Ashgate Publishing Company.

Pp. 43-60.\}

Lynch, Caitrin. 2007. Juki girls, good girls: Gender and cultural politics in Sri Lanka's global garment industry. Ithaca, N.Y.: Cornell University Press.

Malik, A. 2004. Bahrain human rights group dissolved. Associated Press. http://web.lexisnexis.com/universe/document?_m=4025f9a98e2483581f3870d28c6032b8\&_docnum=2\&wchp=dGLbVtzzSkVA\&_md5=d8ea084d65e9ad0d4cc0f85dc8d10e68. Posted 29 September 2004, accessed 27 February 2005. \{CUT this McGilvray reference\} McGilvray, Dennis B. 1998. Arabs, Moors and Muslims: Sri Lankan Muslim ethnicity in regional perspective. Contributions to Indian Sociology 32: 433-83. 
McKay, Deirdre. 2005. Success stories? Filipina migrant domestic workers in Canada. In Huang et al., eds. 2005. 305-38.

Miyoshi, Masao. 1993. A borderless world? From colonialism to transnationalism and the decline of the nationstate. Critical Inquiry 19 (4): 726-51.

Mundlak, Guy. 2005. Recommodifying time: Working hours of "live-in” domestic workers. In Joanne Conaghan and Kerry Rittich, eds. Labour law, work and family: Critical and comparative perspectives. Oxford: Oxford University Press. 125-56.

Nagy, Sharon. 2006. Making room for migrants, making sense of difference: Spatial and ideological expressions of social diversity in urban Qatar. Urban Studies 43 (1): 119-37.

Nicholson, Melanie. 2006. Without their children: Rethinking motherhood among transnational migrant women. Social Text 24 (3): 13-33.

Nonnenmacher, Sophie, et al. 2003. Asian labour migration ministerial consultations, Sri Lanka, 1-3 April 2003:

Compendium on labour migration policies and practices in major Asian labour sending countries. Colombo: International Organization for Migration.

Ong, Aihwa. 2006. Neoliberalism as exception: Mutations in citizenship and sovereignty. Durham, N.C.: Duke University Press.

Ortner, Sherry B. 2006. Anthropology and social theory: Culture, power, and the acting subject. Durham, N.C.: Duke University Press.

Parreñas, Rhacel Salazar. 2001. Servants of globalization: Women, migration, and domestic work. Palo Alto, Calif.: Stanford University Press.

Perera, Viola. 2004. Interview. 1 December. Coordinator, Action Network for Migrant Workers. Nawala, Sri Lanka. Qurtoba Services. 2004. Interview with Qurtoba Services Manpower Recruitment Agency, Ajman, UAE, 9 November.

Rahman, Noor Abdul, Brenda S.A. Yeoh, and Shirlena Huang. 2005. "Dignity overdue”: Transnational domestic workers in Singapore. In Huang et al., eds. 2005. 233-61.

Rose, Nikolas. 1999. Powers of freedom: Reframing political thought. Cambridge: Cambridge University Press.

Rostow, \{Walt Whitman\}. 1960. The stages of economic growth. Cambridge: Cambridge University Press.

Ruhunage, L.K. 2004. Interview, 11 November. Counsellor (Employment and Welfare), Consulate General of the Democratic Socialist Republic of Sri Lanka, Dubai, UAE.

\{CUT this Sassen reference\} Sassen, Saskia. 2002. Global cities and survival circuits. In Ehrenreich and Hochschild. 2002. New York: Metropolitan Books. 254-74.

Sebastian, Michael and Raghwan, eds. 2000. Asia Pacific regional trade union symposium on migrant workers, 6-9 
December 1999, Kuala Lampur, Malaysia. Geneva: ILO.

Shinozaki, Kyoko. 2005. Keeping women \{on the move; delete this bit: *in [sic]*\} the move: Transnational “families' in the Philippines' politics of reproductive labor migration. Paper presented at the conference "Migration and Domestic Work in Global Perspective, 26-29 May 2005. The Netherlands Institute of Advanced Studies, Wassenar.

\{Sim, Amy and Vivianne Wee. 2008. Not sure of the title. I want to reference Amy and Vivienne's article that is part of the 9-paper submission Nicole Constable sent in. Not sure what the new title is; not sure whether her article is in 'this volume' or the prior CAS volume. Please help! Thanks!\}

Sorensen, Ninna Nyberg. 2005. Transnational family life across the Atlantic: The experience of Colombian and Dominican migrants in Europe. Paper presented at the conference "Migration and Domestic Work in Global Perspective, 26-29 May 2005. The Netherlands Institute of Advanced Studies, Wassenar.

Soysa, David. 2004. Interview. 3 February 2004. Migrant Services Centre. Dehiwela, Sri Lanka.

Sri Lankan Bureau of Foreign Employment (SLBFE). 2004. Statistical handbook on migration, 2003. Colombo, Sri Lanka: Research Division, SLBFE.

—. 2006. Statistical handbook on migration, 2005. Colombo, Sri Lanka: Research Division, SLBFE.

Sunday Times. 2008. Crisis is averted over housemaids. The Sunday Times Online, Sunday, 13 January.

http://www.sundaytimes.lk/080113/FinancialTimes/ft326.html (accessed 17 January 2008).

\{Thompson, Edward Palmer. 1963. The making of the English working class. New York: Pantheon Books.\}

Wagner, Heike. 2005. The instruction and the placement of female Ecuadorian domestic workers in a Catholic parish in Madrid. Paper presented at the conference "Migration and Domestic Work in Global Perspective. 26-29 May 2005. The Netherlands Institute of Advanced Studies, Wassenar.

Wanasundera, Leelangi. 2001. Migrant women domestic workers: Cyprus, Greece and Italy. Colombo: Cenwor.

Wee, Vivienne, and Amy Sim. 2005. Hong Kong as a destination for migrant domestic workers. In Huang et al., eds. 2005. 175-209.

Weerakoon, Nedra. 1998. Sri Lanka: A \{caste case\} study of international female labour migration. In S. Sta. M. Amparita, J.J. Balisnono, R. Plaetevoet, and R. Selwyn, eds. Legal protection for Asian women migrant workers: Strategies for action. Makati City, Philippines: Ateneo Human Rights Center. 97-118.

WHO (World Health Organization). 2005. Core indicators 2005: Health situation in the South-East Asia and Western Pacific Regions. Geneva: WHO.

Wijesiri, Dudley. 2004. Interview. 3 February 2004. Migrant Services Centre. Dehiwela, Sri Lanka.

Winkler, Onn. 2005. Was it worth it? A reexamination of the cost/benefit balance of the inter-Arab labor migration. Paper presented at the conference “Transnational Migration: Foreign Labor and Its Impact in the Gulf.” Bellagio, 
Italy. 20-24 June.

Witharana, Manori. 2004. Interview. 5 February 2004. American Center for International Labor Solidarity. Colombo, Sri Lanka

Yapa, Kanti. 2004. Interview. 3 February 2004. IOM (International Organization for Migration). Colombo, Sri Lanka.

Notes

1. I have studied labor migration from Sri Lanka to the Middle East since 1992 (Gamburd 2000, 2005). The data for this paper were gathered during fieldwork done in Sri Lanka (1992-2005) and the UAE (2004). Data include statistical information from the Sri Lanka Bureau of Foreign Employment (SLBFE 2006), as well as qualitative interviews with government bureaucrats, migrant women, and activists in labor unions, migrant worker associations, and international organizations.

2. SLBFE 2006, 57.

3. In 2005, the migrants made up 15 percent of the labor force and 16 percent of the total number of employed people (ibid., 88).

4. Ibid.

5. Ibid., 89.

6. Ibid., 6. Domestic servants are known in Sri Lanka in both English and Sinhala as "housemaids," though their duties exceed those traditionally covered by the term.

7. Jayaweera, Dias, and Wanasundera 2002, 1; SLBFE 2006, 57; Weerakoon 1998, 109.

8. $\quad$ Ong 2006.

9. $\quad$ Rostow 1960; Frank 1966.

10. Escobar 1988; Miyoshi 1993.

11. Gledhill 2007.

12. Chang 2000.

13. Khalaf and Alkobaisi 1999. I use "the Middle East," "West Asia," "Gulf Cooperation Council (GCC)," and "the Gulf" interchangeably to refer to a varied and diverse region with many cultural traditions. This rich complexity gets lost in many Sri Lankan accounts of migration, where migrants are said to work in "Arabia," "the Middle East," or merely "abroad."

14. Ehrenreich and Hochschild 2002; Decena, Shedlin, and Martinez 2006; Harrison 1997.

15. Gamburd 2008; Nicholson 2006.

16. Freeman 2001. 
17. Collier and Yanagisako 1987.

18. Gamburd 2000, 2005.

19. Rahman, Yeoh, and Huang 2005, 255; Lan 2003.

20. Mundlak 2005.

21. Longva 1997.

22. Hugo 2005, 76; Sebastian and Raghwan 2000, 2.

23. Human Rights Watch 2007, 68; ILOLEX 2005.

24. Gamburd 2000.

25. Anderson 2002, 112; Constable 2002, 135; Parrenas 2001, 179.

26. Lynch 2007.

27. See Hugo 2005, 83, regarding Saudi Arabia; Ruhunage 2004, regarding the UAE; and Leonard 2003, 134, 153, regarding the UAE and Kuwait.

28. Lan 2005, 227.

29. Wee and Sim 2005, 193.

30. Sorensen 2005, 4.

31. ILOLEX 2005. The International Labor Organization (ILO) plays a role in regulating transnational labor relations. The ILO has several conventions that cover migrant workers. ILO Convention C97 (Migration for Employment Convention (Revised) 1949 suggests, among other things, that migrants should be subject to the same rules and regulations government labor for citizens, including pay, days off, minimum working age, and the right to join unions and bargain collectively. None of GCC countries has ratified this Convention; neither has Sri Lanka. In the Asia-Pacific region, only New Zealand and Malaysia have ratified Convention No. 97 (Sebastian and Raghwan 2000, i-ii). ILO Convention C143, Migrant Workers (Supplementary Provisions) Convention 1975 suggests that states should respect basic human rights of migrants, that they should police illegal migration, and that they should prosecute manpower traffickers. Neither Sri Lanka, nor any of the main sending countries of domestic labor, nor any of the GCC labor-receiving countries has ratified this convention (ILOLEX 2005). ILO conventions provide an international framework of standards, but are not enforceable. In addition, they do not apply to countries that have not ratified them.

32. Weerakoon 1998, 107.

33. Leonard 2003, 145.

34. Guest workers make up high percentages of populations in GCC countries including UAE (75-81 percent), Kuwait (64-66 percent), and Qatar (70-77 percent) (Kapiszewski 2006, 4; Leonard 2003, 136-37; Nagy 2006, 119). 
35. Kapiszewski 2006, 4; Khalaf and Alkobaisi 1999, 272; Leonard 2003: 133.

36. Kapiszewski 2006, 4.

37. Khalaf 1992, 65-66; Winkler 2005, 10.

38. Gardner \{personal communication $\{$ CITE $\}$.

39. Addleton 1991; Looney 1992.

40. Khalaf 1992, 72.

41. Khalaf and Alkobaisi 1999, 294; Longva 1997.

42. Foucault 1979; Rose 1999.

43. Khalaf and Alkobaisi 1999: 274.

44. Leonard 2003, 133.

45. Qurtoba Services 2004.

46. See also, Rahman, Yeoh, and Huang 2005, 242-43.

47. Leonard 2003, 133; Winkler 2005, 18.

48. Kapiszewski 2006, 6; Winkler 2005, 18.

49. Kapiszewski 2006, 5.

50. Khalaf and Alkobaisi 1999, 284.

51. An international branch of the American Federation of Labor and Congress of Industrial Organizations (AFL-CIO), ACILS has been active in Sri Lanka for roughly twenty years (with a hiatus between 1988 and 1993 , during the peak of civil unrest in the southern parts of the island) (Conklin 2004).

52. Soysa 2004; Wijesiri 2004.

53. Wijesiri 2004.

54. ACT FORM was formed in 1999 and has been active since 2001 (Perera 2004).

55. ACT FORM 2003a, 2003b, 2004.

56. IOM has been active in Sri Lanka since 1990 and set up an office there in 2002 (Yapa 2004).

57. Iredale 2003; Nonnenmacher et al. 2003.

58. Conklin 2004; Witharana 2004.

59. Conklin 2004.

60. Jayawardena and de Alwis 2002, 257. 
61. Jayawardena 1973.

62. ACILS is a local branch of the AFL-CIO. MSC is affiliated with Sri Lanka's National Workers' Congress and the All Ceylon Federation of Free Trade Unions (Witharana 2004). Locally, the Ceylon Workers Congress, the plantation workers' trade union, does some organizing on behalf of their constituents who have migrated abroad (Wijesiri 2004).

63. Conklin 2004.

64. Bass 2004.

65. Hewamanne 2008.

66. Conklin 2004.

67. Shinozaki 2005, 7-8.

68. Gamburd 2008, 12-13.

69. Jayaweera 2002a, 16, 19.

70. Jayaweera 2002b, 102-4.

71. Goonasekere 2002: 55; WHO 2005. Compare the situation in the United States, where women make up between 15 and 20 percent of most representative legislative bodies.

72. Jayaweera 2002b, 137.

73. Jayawardena and de Alwis 2002, 257.

74. Sunday Times 2008.

75. DGMF 1998, 7; emphasis added.

76. DGMF 1998, 7.

77. Afsar 2005, 129.

78. Conklin 2004.

79. Afsar (2005) makes a similar point about Bangladesh. She notes that the government organ regulating migration, the Ministry of Expatriate Welfare and Overseas Employment (MEWOE), is quite small relative to the needs of migrants, operates on a very small budget, and receives a low priority among government programs.

Bangladesh has only a few overseas labor attachés, and most migrants are unaware of available diplomatic services abroad. Afsar suggests that "greater efforts and commitment on the part of the government are needed to transform safe migration from rhetoric to reality” (2005: 127).

80. Conklin 2004; Fernando 2004.

81. Sebastian and Raghwan 2000, 4; Weerakoon 1998, 114. 
82. \{source Khalaf\}1992: 58.

83. Malik 2004.

84. Financial Times Information 2004.

85. Ruhunage 2004.

86. Wee and Sim 2005, 184.

87. Ibid., 197.

88. Ibid., 194. See also Constable, this volume.

89. Constable 2007.

90. Wee and Sim 2005, 198.

91. Rahman, Yeoh, and Huang 2005, 251.

92. Ibid., 241-42.

93. Constable, this volume; Sim and Wee, this volume.

94. Personal communication.

95. Andall 2005, 16.

96. Wagner 2005, 10.

97. Hess 2005, 3.

98. Lutz and Schwalgin 2005, 4-5 \{(Find new reference in 2008 book). $\}\{$ Lutz 2008\} \{Delete the prior reference....\}

99. Wee and Sim 2005, 177; Liebelt 2008. \{add Liebelt to refs\} \{Tom: I’m referring to Claudia Liebelt's article that I believe is part of Nicole's package of articles for this and the prior CAS volume. Do you have a citation for the published work? Otherwise I can add a citation from Claudia's conference paper. Could I say Liebelt this volume?\}

100. Hugo 2005, 84.

101. \{Hugo? No.\} \{Asis\} 2005, 44.

102. Wee and Sim 2005, 197-98.

103. Lan 2005, 226; 2006; Rahman, Yeoh, and Huang 2005, 251.

104. SLBFE 2006, 1, 57. In 2005, housemaids made up 54 percent of the total migrants and 91 percent of the female migrants (SLBFE 2006, 6). The majority of female migrants are between twenty-five and forty-five years of age (SLBFE 2006, 56). SLBFE figures indicate that approximately 720,000 of the estimated 800,000 Sri Lankan women working abroad are working as domestic servants in the Gulf (SLBFE 2006, 57). 
105. Asis 2005, 25.

106. Asis notes that Filipinos gather at public spaces such as "Lucky Plaza in Singapore, Chongshan North Road in Taipei, [and] Central in Hong Kong” (2005: 37) and socialize at the Catholic Church in many labor-receiving countries (2005: 45). All the notable gathering places mentioned by Asis are in Asian, not Middle Eastern, countries.

107. Asis 2005, 25; SLBFE 2004, 23.

108. Asis 2005, 28.

109. IPS 2004, ix.

110. Thompson 1963.

111. Asis 2005, 25; Wee and Sim 2005, 195.

112. McKay 2005, 310.

113. Parreñas 2001, 19.

114. Gunatillake and Perera 1995, 43.

115. Weerakoon 1998, 102.

116. Emerging ethnographic data (Gamburd 2008) suggests that a second generation, the educated daughters of Middle East migrants, are taking jobs outside the Middle East, for example as care-providers in Israel or seamstresses in Italy. This suggests that in the next ten years, Sri Lanka's migrant profile (and hopefully its laborers' empowerment abroad) may undergo a shift for the better.

117. Constable 2007, 32.

118. Ibid., viii.

119. Gamburd 2008\{; Wanasundera 2001.\}

120. Asis 2005, 44-45. Hugo (2005, 69) makes similar claims about the Indonesian government's lack of “commitment to protect Indonesian workers in foreign nations.” Roughly 42 percent of Indonesian migrants go to Saudia Arabia and the UAE, while 58 percent go to Asian destinations, particularly Malaysia and Singapore (Hugo 2005, 60). Hugo suggests that the Philippines has done more than Indonesia has in sending labor attachés to destination countries and working for bilateral and multilateral labor agreements. Both countries’ governments could support NGO activities in destination countries if the local governments limit the powers of diplomatic officials. But here again, NGO activity is more accepted in Asian than in Middle Eastern destinations.

121. Ortner 2006. 